\title{
Combined application of microbial consortium and humic substances to improve the growth performance of blueberry seedlings
}

\author{
Mauricio Schoebitz ${ }^{1 *}$, M.D López ${ }^{2}$, Humberto Serrí ${ }^{2}$ Oscar Martínez ${ }^{3}$, Erick Zagal ${ }^{1}$
}

${ }^{1}$ Departamento de Suelos y Recursos Naturales. Facultad de Agronomía, Campus Concepción, Casilla 160-C. Universidad de Concepción, Chile. ${ }^{2}$ Departamento de Producción Vegetal. Facultad de Agronomía, Campus Chillán. Universidad de Concepción. Instituto de Bioquímica y Microbiología, Facultad de Ciencias, Universidad Austral de Chile. *Corresponding author: mschoebitz@udec.cl

\begin{abstract}
A field experiment was carried out to assess the effectiveness of microbial consortium (bacteria and fungi) and humic substances separately, as well as the effect of the combined application of them on the growth of blueberry (Vaccinium corymbosum L.) seedlings and the physicochemical and biological properties of a volcanic ash-derived soil. One year after seedlings were planted, the treatment consisting of the combined application of microbial consortium and humic substances was the most effective, recording a $50 \%$ increase in shoot dry weight and a $43 \%$ increase in root dry weight compared to the control plants. Similarly, the microbial inoculant treatment also showed increased shoot and root dry weights, with values $32 \%$ and $31 \%$ higher than the control plants. The combined application of microbial consortium and humic substances improved nitrogen and potassium uptake compared to the unamended soil. Regarding soil properties, the soil nitrate content was higher when applying the humic substances alone, while changes were also observed in the rhizobacterial community composition. This suggests that the use of humic substances substantially modifies the bacteriological characteristics, but not the mycological characteristics of the rhizosphere. The combined treatment had positive effects on both plant performance and nutrients uptake in a volcanic ash-derived soil.
\end{abstract}

Keywords: Andisol, biofertilization, nutrient uptake, amendments, soil microorganisms

\section{Introduction}

Vaccinium corymbosum L. (Ericaceae) is a highly valued fruit crop and the most common type of blueberry grown in Chile (Retamales et al., 2014). Chile has become the most important producer and exporter of blueberry in the southern hemisphere. The planted surface has steadily increased to 14,753 ha since blueberries were first introduced into the country (ODEPA, 2014). Plant growth and yield crop production are affected by agricultural practices and different soil parameters including physical, chemical and biological properties. Among the different methods for enhancing nutrient quantity 
and availability for the plant is the use of chemical fertilization, which is a fast way of providing plantessential nutrients. Numerous studies have shown the negative effects that chemical fertilizers have on the environment as a result of leaching and runoff of nutrients, leading to environmental degradation. Important reasons for these problems are low use efficiency of fertilizers and their continuous long-term use (Adesemoye et al., 2009). Therefore, the use of beneficial soil microorganisms has a potential role in developing sustainable systems for crop production (Couillerot $e t$ al., 2013). Plant growth-promoting microorganisms (PGPM), such as bacteria and fungi,are an important part of the soil microbiota, which are known for their capacity to promote biological nitrogen fixation, phosphate solubilization,indole acetic acid production, increase the root surface area and improve plant growth (Bashan et al., 2014; Viscardi et al., 2016). PGPM may enhance plant growth by improving the supply nutrients characterized by a low mobility in the soil (Schoebitz and Vidal, 2016). In this regard, plant growth-promoting microbial consortium may have a potential role in the plant performance of blueberry seedlings under field conditions in volcanic soils.

The beneficial effects of humic substances on plant growth may be related to increased fertilizer efficiency, reducing soil compaction, enhancing plant biomass (Canellas et al., 2015) and increasing soil microflora (Puglisi et al., 2013). Humic substances do not only have a positive effect on soil fertility, resulting in a higher nutrient availability for plant growth, but they also seem to positively influence metabolic and signaling pathways involved in plant nutrient uptake (Kolodziej et al., 2013). In some cases, a better crop response was observed using humic-like substances obtained from compost instead of humic extracts from leonardite (the most common commercial source) (Canellas et al., 2015). Many commercial products containing humic substances, most commonly humic acid, are currently being used in commercial vegetable production; these products are frequently applied into the soil. Although the potential activity of products containing humic acid has been well documented,there are serious limitations in the existing scientific literature (i.e. highly dependent on plant genotype and application rate) (Hartz and Bottoms 2010).

Some recent studies have described the beneficial effects of humic acid combined with inoculated beneficial bacteria. A study conducted by Olivares et al. (2015) showed beneficial effects on the chemical soil properties and plant performance when humic acid wasapplied in combination with Herbaspirillum seropedicae as plant growth promoting bacteria. Furthermore, Canellas and Olivares (2014) have studied the basic mechanisms and benefits of the combined application of humic substances and plant growth-promoting bacteria in different types of crops, reporting findings that provide evidence that humic acids can promote beneficial soil microbial growth. The effect of humic substances combined with bacteria in foliar applications has been studied in maize grown under field conditions, resulting in a $65 \%$ increase in grain production compared to the untreated control (Canellas et al., 2015).

The main objective of our study was to assess the effect of the combined application of a single dose of humic substances and microbial consortium (bacteria and fungi) on the growth performance of blueberry seedlings and nutrient uptake under field conditionsin a volcanic ash-derived soil. We hypothesize that the effect of the combined application of microbial consortium and humic substances into the soil can effectively improve the physicochemical and biological properties of the soil, promote plant growth and increase nutrient availability. 


\section{Materials and Methods}

\subsection{Study site}

The experiment was located at El Nogal Experimental Station of the University of Concepción in Chillán, Chile ( $36^{\circ} 35^{\prime} 43.2^{\prime \prime}$ S, $72^{\circ} 04^{\prime} 39^{\prime \prime} \mathrm{W}, 144$ m.a.s.l.). The climate at this location is classified as temperate Mediterranean, with an annual rainfall of $980 \mathrm{~mm}$ per year, concentrated in winter, with a potential evapotranspiration of $818 \mathrm{~mm}$. Annual mean temperature is $13{ }^{\circ} \mathrm{C}$, with an average temperature of $7{ }^{\circ} \mathrm{C}$ in July and $20{ }^{\circ} \mathrm{C}$ in January. Annual mean relative humidity is $74 \%$ and the frost-free period is 6 months (del Pozo y del Canto, 1999). Soil is classified as medial, amorphic, thermic Humic Haploxerands, derived from a volcanic ash-derived soil (Andisol) (SSS, 2006). The physical and chemical properties of the soil are described in Table 1.

Table 1. Physico-chemical characteristics of the soil used in the experiment.

\begin{tabular}{ll}
\hline & Soil \\
\hline $\mathrm{pH}$ & 6.74 \\
Organic matter (\%) & 5.77 \\
$\mathrm{NO}_{3}\left(\mathrm{mg} \mathrm{kg}^{-1}\right)$ & 11.6 \\
Available P $\left(\mathrm{mg} \mathrm{kg}^{-1}\right)$ & 77.3 \\
Extractable K $\left(\mathrm{mg} \mathrm{kg}^{-1}\right)$ & 406.3 \\
Clay (\%) & 22.7 \\
Silt (\%) & 36.8 \\
Sand (\%) & 40.5 \\
Texture & Loam \\
Macro aggregates (\%) & 93.2 \\
Micro aggregates (\%) & 2.7 \\
\hline
\end{tabular}

\subsection{Plants}

Highbush blueberry Vaccinium corymbosum L. var. Legacy, which belongs to the Ericaceae family, was used in this study. Seedlings were grown in ProPlantnursery (Chillán, Chile) with soil as substrate for 18 months prior to experimental procedures. At planting, V. corymbosum was $70.5 \pm 8.2 \mathrm{~cm}$ high, with a shoot dry weight of $6.8 \pm 1.2 \mathrm{~g}$, root dry weight of $8.0 \pm$ $1.0 \mathrm{~g}$, diameter $4.9 \pm 0.1 \mathrm{~mm}, \mathrm{~N}$ total $32 \mathrm{mg} \mathrm{plant}^{-1}$, $\mathrm{P}$ total $3 \mathrm{mg}$ plant $^{-1}$ and $\mathrm{K}$ total $2.6 \mathrm{mg}$ plant $^{-1}(\mathrm{n}=3)$.

\subsection{Plant growth-promoting microbial consortium and humic substances}

Commercial microbial consortium Oiko bac 174 (Oikos Chile Ltda) was evaluated in terms of plant performance and plant nutrient uptake. This consortium contained soil beneficial microorganisms belonging to bacteria and fungi. The beneficial microbial consortium was a mixture of ten soil microorganisms: Bacillus subtilis, Bacillus licheniformis, Bacillus megaterium, Bacillus polymyxa, Bacillus macerans, Pseudomonas fluorescens, Pseudomonas putida, Nocardiac orallina, Saccharomyces cerevisiae and Trichoderma viride, being the cell concentrations of tenmicroorganisms $10^{8} \mathrm{CFU} \mathrm{g}^{-1}$. Therefore, $50 \mathrm{~g}$ of microbial consortium and $100 \mathrm{~g}$ of saccharose were dissolved in $10 \mathrm{~L}$ of tap water (based on the manufacturer's recommendations). Microbial consortium was applied at planting and reapplied every two months from August 2014 to March 2015. Biosolve, which is a commercial product (Oikos Chile Ltda) containing humic acid (derived from leonardite shale), was used as humic substance for the soil ( $70 \%$ of humic acid, $15 \%$ of fulvic acid and $10 \%$ of $\mathrm{K}_{2} 0 \mathrm{w} / \mathrm{w}$ ). At planting, $15 \mathrm{~g}$ of humic substances (powder form) was added per seedling. Humic substances was applied once and 
manually mixed into the soil and introduced in the plantation holes.

\subsection{Experimental design}

A full- factorial design was established with two factors and 5- fold replications in a split plot design. The first factor was the inoculation or not of blueberry seedlings with microbial consortium and the second was the addition or not of humic substances into the soil.

Twenty seedlings were transported to the experimental field in April 2014, where planting holes 30 × 30 $\mathrm{cm}$ wide and $30 \mathrm{~cm}$ deep were dug manually. Then, an amount of $1 \mathrm{~L}$ of microbial consortium was applied per plantafter planting. The same quantity of sterilized inoculant was applied to the non-inoculatedcontrol plants. The seedlings were planted at least $1 \mathrm{~m}$ apart between holes and rows were spaced $3 \mathrm{~m}$ apart. At planting, an amount of $120 \mathrm{~g}$ of ammonia sulphatewas applied into the soil in all of the treatments to reduce soil $\mathrm{pH}$.

\subsection{Sampling procedures}

Samples were collected by May 2015. Five plants per treatment, including root systems and rhizosphere soil, were harvestedand placed in polyethylene bags to be transported to the laboratory. Rhizosphere soil samples were separated into two subsamples before chemical and microbiological analyses. Fruits were not analyzed because not all of the treatments included fruits.

\subsection{Plant and soil properties}

To evaluate the response to microbial consortium inoculation and humic substances, the following growth parameters were considered and values were recorded before the chemical analysis: stem diameter, plant height, and shoot and root dry weights $\left(70^{\circ} \mathrm{C} ; 24 \mathrm{~h}\right)$. Foliar concentrations of $\mathrm{N}, \mathrm{P}$ and $\mathrm{K}$ were determined according to the methodology described by Sadzawka et al. (2007). The $\mathrm{N}$ content in the soil was measured using dry combustion in a total elemental analyzer (LECO, TruSpec CN). Soil pH was measured in a 1:2.5 $(\mathrm{w} / \mathrm{v})$ aqueous solution. Available nitrogen $\left(\mathrm{NO}_{3}\right)$, extractable potassium $(\mathrm{K})$ and organic matter $(\%)$ were determined as proposed by Sadzawka et al. (2006).

\subsection{Soil physical properties}

Soil samples were taken from each treatment and bulk density was determined by using PVC cylinders $(3.5 \times 30 \mathrm{~cm})$. These samples were then oven-dried $\left(105^{\circ} \mathrm{C}\right)$ until reaching constant weight (Blake and Hartge, 1986).

Air-dried aggregate samples of $100 \mathrm{~g}$ were brought to saturation and placed on the top of six nested sieves $(4.0,2.0,1.0,0.5,0.25$ and $0.05 \mathrm{~mm})$, which were in a container holding water. The soil and sieves were subsequently submerged in the water (35 $\mathrm{mm}$ depth) and agitated for $30 \mathrm{~min}$ at 25 cycles per $\mathrm{min}^{-1}$ (Sandoval et al., 2007). The water-stable aggregates that were distributed in the different-sized sieves were placed in a drying oven at $105^{\circ} \mathrm{C}$ for $24 \mathrm{~h}$, and afterwards weighed to determine the total weight of aggregates within each size range.

The samples from the pots were air-dried and sieved to $2 \mathrm{~mm}$, and then taken to laboratory to be analyzed using the method described by Klute (1986), which consisted of placing $25 \mathrm{~g}$ of soil per treatment in rubber rings placed on ceramic plates in a pressure chamber. Subsequently, samples were soaked in water for $24 \mathrm{~h}$ by capillary action. After this period, they were pressured at $3.3 \mathrm{MPa}$ and 
148.5 MPa, corresponding to field capacity and permanent wilting point, respectively. Plant available water (AW) is the difference between field capacity and permanent wilting point and corresponds to the amount of water in the soil that is potentially available for plant uptake. A particle density value of $2.55 \mathrm{~g} \mathrm{~cm}^{-3}$ was used to calculate total porosity.

\subsection{DNA fingerprinting analysis structures of bacterial and fungal communities}

The effect of the combined application of microbial consortium and humic substances on the structure of bacterial and fungal communities in rhizosphere soils was evaluated by polymerase chain reaction-denaturing gradient gel electrophoresis (PCR-DGGE) as described by Jorquera et al. (2010), using a specific primer set for bacterial $16 \mathrm{~S}$ rRNA gene and fungal $18 \mathrm{~S}$ rRNA gene. DNA was extracted with Ultraclean Soil DNA Isolation Kit (Mo-Bio Laboratories) according to the manufacturer's instructions. The PCR-DGGE analysis was performed in a $9 \%(\mathrm{w} / \mathrm{v})$ polyacrylamide gel with a gradient of $30 \%$ and $70 \%$ (urea and formamide). The electrophoresis was run for $12 \mathrm{~h}$ at $100 \mathrm{~V}$, and then the gels were stained with SYBR Gold (Molecular Probes, Invitro gen Co.) for 30 min and photographed on an UV transilluminator. PCR-DGGE band profiles were compared and dendrograms were generated using Phoretix 1D analysis software (TotalLab Ltd.). Similarities in community composition between samples were calculated by the Bray-Curtis method and visualized using a non-metric multidimensional scaling (nMDS) based on PAST freeware (http://folk.uio. no/ohammer/past/). The structural diversity of bacterial and fungal communities was assessed by the Shannon index based onthe PCR-DGGE profiles (Girvan et al., 2003).

\subsection{Statistical analysis}

Values were log- and arcsine-transformed to achieve normality. The values indicating the effects exerted by both HA and MC treatments, either alone or in combination, were analyzed by a two-way ANOVA and a post-hoc mean separation was performed by Duncan's multiple range test, calculated at $\mathrm{P} \leq 0.05$. All statistical analyses were performed using SPSS software (version 19.0 for Windows).

\section{Results}

3.1. Effect of the inoculation with microbial consortium and humic substances on the growth of blueberry plants

The inoculation with microbial consortium (MC) promoted an increase in shoot and root dry weights, with $32 \%$ and $31 \%$ increases, respectively. On the other hand, the combined treatments of microbial consortium and humic substances (MC+HA) had a $50 \%$ increase in shoot dry weight and a $43 \%$ increase in root dry weight compared to the control plants (Table 2). The humic substances treatment (HA) did not show a significant effect on shoot or root dry weights. Regarding plant height, the combined $\mathrm{MC}+\mathrm{HA}$ treatments presented a $16 \%$ increase compared to the values observed in the control plants. The experimental factors tested did not significantly affect basal stem diameter (Table 2). 
Table 2. Effect of inoculation with microbial consortium and addition of humic acid on growth parameters of blueberry seedlings.

\begin{tabular}{lllll}
\hline & $\begin{array}{l}\text { Basal stem } \\
\text { diameter }(\mathrm{mm})\end{array}$ & $\begin{array}{l}\text { Height plant } \\
(\mathrm{cm})\end{array}$ & $\begin{array}{l}\text { Root dry } \\
\text { weight }(\mathrm{g})\end{array}$ & $\begin{array}{l}\text { Shoot dry } \\
\text { weight }(\mathrm{g})\end{array}$ \\
\hline Control & $7.7 \pm 0.3 \mathrm{a}$ & $81 \pm 2 \mathrm{a}$ & $36 \pm 1.4 \mathrm{a}$ & $34 \pm 6.3 \mathrm{a}$ \\
$\begin{array}{l}\text { Microbial consortium } \\
\text { (MC) }\end{array}$ & $8.2 \pm 0.7 \mathrm{a}$ & $90 \pm 4 \mathrm{ab}$ & $47 \pm 3.7 \mathrm{~b}$ & $45 \pm 7.5 \mathrm{~b}$ \\
Humic acid (HA) & $7.6 \pm 0.3 \mathrm{a}$ & $82 \pm 3 \mathrm{ab}$ & $29 \pm 3.2 \mathrm{a}$ & $27 \pm 5.0 \mathrm{a}$ \\
MC+HA & $9.0 \pm 0.8 \mathrm{a}$ & $94 \pm 4 \mathrm{~b}$ & $51 \pm 3.4 \mathrm{~b}$ & $51 \pm 6.4 \mathrm{~b}$ \\
\hline
\end{tabular}

Values are means of five replicates. Significant difference according to Duncan test at $p \leq 0.05$ levels are indicated by different letters).

\subsection{Nutrient uptake and soil chemical properties}

The experimental treatments did not significantly affect the total shoot Pcontent (Table 3). However, the total $\mathrm{N}$ concentration in the plants increased significantly in the $\mathrm{MC}+\mathrm{HA}$ treatments (55\%). In addition, the humic substances treatment showed a statistically significant decrease of $55 \%$ in shoot $\mathrm{N}$ content. The total $\mathrm{K}$ concentration in shoots increased significantly in the $\mathrm{MC}+\mathrm{HA}$ treatments, reaching values $56 \%$ greater than the control plants.
No significant differences among microbial consortium, humic substances and $\mathrm{MC}+\mathrm{HA}$ treatments were found for $\mathrm{pH}$, organic matter $\mathrm{N}$ total and $\mathrm{K}$ extractable (Table 4). However, the nitrate concentration in the soil was significantly higher in the humic substances treatments, with a $63 \%$ and a $90 \%$ increase compared to the control and MC treatments, respectively.

Table 3. Foliar nutrients of blueberry seedlings in response to the addition of microbial consortium and humic acid measured 1 year after planting $(n=5)$

\begin{tabular}{llll}
\hline & $\mathrm{N}\left(\mathrm{g} \mathrm{plant}^{-1}\right)$ & $\mathrm{P}\left(\mathrm{g} \mathrm{plant}^{-1}\right)$ & $\mathrm{K}\left(\mathrm{g} \mathrm{plant}^{-1}\right)$ \\
\hline Control & $0.22 \pm 0.03 \mathrm{~b}$ & $0.04 \pm 0.01 \mathrm{ab}$ & $0.27 \pm 0.03 \mathrm{ab}$ \\
Microbial consortium (MC) & $0.27 \pm 0.02 \mathrm{bc}$ & $0.05 \pm 0.01 \mathrm{ab}$ & $0.37 \pm 0.03 \mathrm{bc}$ \\
& & & \\
Humic acid (HA) & $0.12 \pm 0.03 \mathrm{a}$ & $0.03 \pm 0.005 \mathrm{a}$ & $0.20 \pm 0.05 \mathrm{a}$ \\
MC+HA & $0.34 \pm 0.02 \mathrm{c}$ & $0.06 \pm 0.01 \mathrm{~b}$ & $0.42 \pm 0.03 \mathrm{c}$ \\
\hline
\end{tabular}

Values are means of five replicates. Mean \pm standard error.

Values followed by the same letter in the columns do not differ significantly $(p \leq 0.05)$ by Duncan test. 


\subsection{Soil physical properties}

No significant effects were observed on aggregates stability, bulk density, total porosity and soil available water with any of the treatments studied (Table 4). In many cases, a significant increase in the values for these treatments was not confirmed by the Duncantest, whereas the percentage of soil particle aggregation showed a statistically significant reduction by the humic substances treatment compared to the control plants.

Table 4. Changes in chemical and physical soil properties on blueberry seedlings in response to microbial consortium and humic acid addition.

\begin{tabular}{|c|c|c|c|c|c|c|c|c|c|}
\hline & $\mathrm{pH}$ & $\begin{array}{l}\text { Organic } \\
\text { Matter (\%) }\end{array}$ & $\begin{array}{l}\text { Nitrate } \\
\left(\mathrm{mg} \mathrm{kg}^{-1}\right)\end{array}$ & $\mathrm{N}$ total $(\%)$ & $\begin{array}{l}\text { K extractable } \\
\left(\mathrm{mg} \mathrm{kg}^{-1}\right)\end{array}$ & $\begin{array}{l}\text { Bulk density } \\
\left(\mathrm{g} \mathrm{cm}^{3}\right)\end{array}$ & $\begin{array}{l}\text { Total Porosity } \\
(\%)\end{array}$ & $\begin{array}{l}\text { Aggregates } \\
\text { stability (\%) }\end{array}$ & $\begin{array}{l}\text { Soil available } \\
\text { water }(\%)\end{array}$ \\
\hline Control & $5.5 \pm 0,2 \mathrm{a}$ & $5.5 \pm 0.3 \mathrm{a}$ & $3.5 \pm 0.5 \mathrm{a}$ & $0.33 \pm 0.02 \mathrm{a}$ & $149 \pm 15 \mathrm{a}$ & $0.89 \pm 0.01 \mathrm{a}$ & $65.1 \pm 0.2 \mathrm{a}$ & $80.4 \pm 1.20 \mathrm{~b}$ & $18.2 \pm 0.3 \mathrm{a}$ \\
\hline $\begin{array}{l}\text { Microbial } \\
\text { consortium (MC) }\end{array}$ & $5.3 \pm 0.3 \mathrm{a}$ & $5.8 \pm 0.2 \mathrm{a}$ & $3.0 \pm 0.4 \mathrm{a}$ & $0.34 \pm 0.02 \mathrm{a}$ & $154 \pm 26 a$ & $0.90 \pm 0.01 \mathrm{a}$ & $64.8 \pm 0.3 \mathrm{a}$ & $79.6 \pm 0.56 \mathrm{ab}$ & $18.7 \pm 0.7 \mathrm{a}$ \\
\hline Humic acid (HA) & $5.5 \pm 0.3 \mathrm{a}$ & $5.3 \pm 0.1 \mathrm{a}$ & $5.7 \pm 0.4 b$ & $0.30 \pm 0.01 \mathrm{a}$ & $142 \pm 11$ a & $0.89 \pm 0.01 \mathrm{a}$ & $65.2 \pm 0.5 \mathrm{a}$ & $77.0 \pm 0.46 \mathrm{a}$ & $18.8 \pm 1.3 \mathrm{a}$ \\
\hline $\mathrm{MC}+\mathrm{HA}$ & $5.6 \pm 0.1 \mathrm{a}$ & $5.5 \pm 0.1 \mathrm{a}$ & $2.8 \pm 0.5 \mathrm{a}$ & $0.30 \pm 0.01 \mathrm{a}$ & $149 \pm 14 \mathrm{a}$ & $0.89 \pm 0.0$ a & $65.0 \pm 0.1 \mathrm{a}$ & $78.8 \pm 0.56 \mathrm{ab}$ & $19.7 \pm 1.5 \mathrm{a}$ \\
\hline
\end{tabular}

Values are means of five replicates. Mean \pm standard error.

Values followed by the same letter in the columns do not differ significantly $(p \leq 0.05)$ by Duncan test.

\subsection{Structure of bacterial and fungal communities}

Figures 1 and 2 show the dendrograms and nMDSplots describing the effect of the application of microbial consortium and humic substances on the structure of bacterial and fungal communities in the rhizosphere of blueberry plants. Humic substances and the combined application of microbial consortia plus humic substances induced significant changes in the structure of bacterial populations respect to the control treatment as revealed by nMDS (Figure 1); however, no significant changes were observed with the microbial consortium inoculation. On the other hand, the
nMDS analysis showed no significant changes in the structure of fungal communities in the treatments (Figure 2). In the case of bacterial communities, the Shannon index values representing bacterial diversity were higher (2.25), but not statistically significant $(\mathrm{P} \leq 0.05)$ for the treatments compared to the control. On the other hand, significant differences were found between the Shannon index values obtained from the DGGE analysis of fungal communities; the Shannon index was significantly higher in all treatments except in the control. 


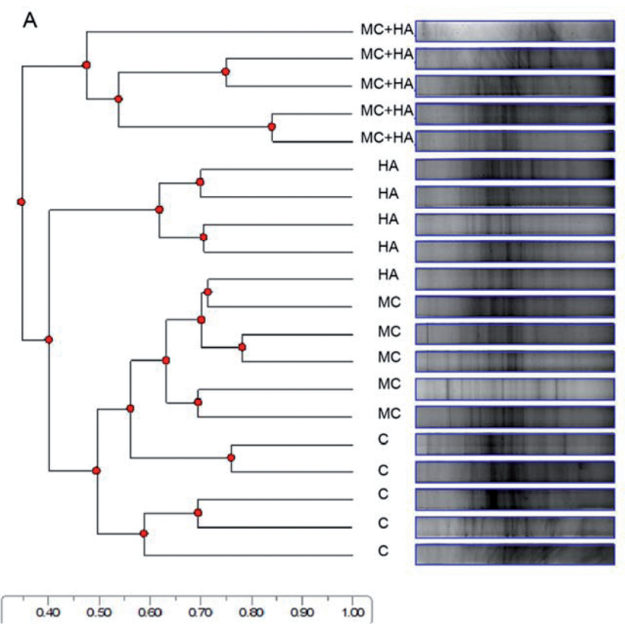

A

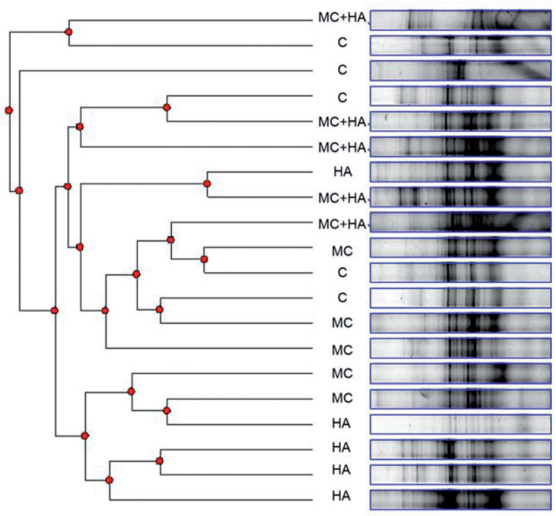

as5 $060 \quad 065 \quad 070 \quad 0.750 .20 \quad 0.550 .90 \quad 0.95 \quad 1.00$

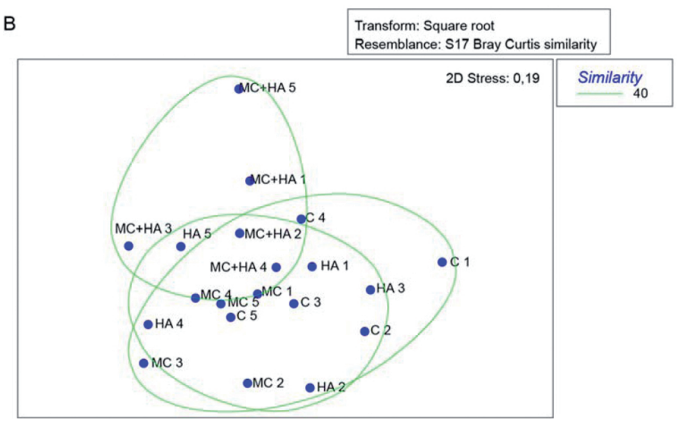

Figure 2. Dendrogram (A) and non-metric multidimensional scaling (nMDS) analysis (B) of PCR-DGGE profiles 18S rRNA gene from fungal communities $(\mathrm{C}$ : control; $\mathrm{MC}$ : microbial consortia; HA: humic acid; $\mathrm{MC}+\mathrm{HA}$ : microbial consortium + humic acid). ( $\mathrm{n}=5)$ 


\section{Discussion}

The results demonstrate that the combined application of MC and HA was the most-effective treatment for promoting plant growth and nutrient uptake under field conditions. Inoculation with plant growth-promoting microbial consortium has shown to be a useful strategy to promote theplant growth (Thilagar et al., 2016). Plants showed different levels of response to the $\mathrm{MC}$ and the addition of the humic substances. An increase in biomass was observed with microbial consortium and the $\mathrm{MC}+\mathrm{HA}$ treatments. In contrast, no significant differences were observed when HA alone was applied to the soil. These results do not agree with previous research in which the effect of the application of humic substances into the soil was also studied. In fact, Rose et al. (2014) reported that shoot and root dry weights of different plants under study increased $22 \%$ in response to the application of humic acid. It is also important to highlight that plant responses to humic acids eems to be highly dependent on plant species, rate of application, source of humic acid and mode of application (foliar spray or direct soil drench).

However, our results are in agreement with those described by Pirlak and Köse (2009), who reported an increase in the yield of strawberry plants after the inoculation with microbial consortium. It is well documented that soil microorganisms exert a beneficial effect on plant growth and development. In fact, many different microorganisms are being commercialized to be used in agriculture (Adesemoye et al., 2009; Bashan et al., 2014). Besides, the development of a plant-growth-promoting consortium could be a with feasible strategy to enhance the use of plant-growthpromoting bacteria and fungi (Singh et al., 2010). When these strains are made into aconsortium, each of the constituent strains does not only compete with the others for rhizosphere establishment but it is also functionally for plant growth promotion. Depending on the strain combination, microbial interactions within these consortia can have either positive or negative effects on inoculant establishment and may result or not in enhanced plant growth in comparison with single inoculation (Couillerot et al., 2013). According to Jha and Saraf (2012) root and shoot biomass were maximized with microbial consortium compared to both control and individual trials of microorganisms. Plant growth, nutrition, yield, mycorrhizal root colonization in the rhizosphere were found to be higher when Paenibacillus polymyxa, Pantoea agglomerans and Funneliformis mosseae were applied simultaneously compared to both the control and their individual inoculation (Chauhan and Bagyaraj 2015). This is a well-known strategy that enables organisms to successfully survive and maintain themselves in communities. Previous microbial studies performed without plants have indicated that some combinations allow bacteria to interact with each other synergistically, providing nutrients and stimulating each other through physical and biochemical activities that may enhance some beneficial aspects of their physiology (Jha and Saraf, 2012). MC+HA was the treatment with the best response, reaching the most significant increases in nutrient uptake. $\mathrm{MC}, \mathrm{HA}$ and $\mathrm{MC}+\mathrm{HA}$ did not increase the total $\mathrm{P}$ content in our experiment with blueberry seedlings. However, the $\mathrm{MC}+\mathrm{HA}$ treatment proved effective for improving the uptake of other nutrients such as $\mathrm{N}$ and $\mathrm{K}$, which might explain why the combined treatment yielded the highest shoot biomass. Higher K uptake may be attributable to the mobilization of nutrients from the soil because of the secretion of organic acids mediated by soil microorganisms (Basak and Biswas 2010). Esitken et al. (2010) conducted a field experiment adding microbial consortium to the soil and found an increase of $\mathrm{P}$ uptake, but not for $\mathrm{N}$ and $\mathrm{K}$ in strawberry plants three years after the inoculation of Bacillus sp. and 
Pseudomonas sp in a combined treatment. According to Orhan et al. (2006), microbial consortium (two Bacillus strains) did not increase the total $\mathrm{K}$ in other field experiment using raspberries, but resulted in a significant increase in $\mathrm{N}$ content and $\mathrm{P}$ uptake compared to the untreated control. Recently, humic acid was applied in combined treatment with Herbaspirillum seropedicaeas plant growth promoting bacteria (Olivares et al., 2015). As humic acids are considered recalcitrant to microbial activity, these substances can be used as a carrier to introduce beneficial microorganisms in the field. Therefore, acombined application of humic acid and beneficial soil microorganisms increases plant performance and nutrient uptake. Changes in plant metabolism in response to these treatments were associated with increased plant production (Olivares et al., 2015).

Beneficial soil microorganisms are rhizosphere-competent and can colonize most of ecological niches established in the rhizosphere thus reaching and mobilizing a wider range of nutrients (Bashan et al., 2014). In this sense, total nutrient content can be taken as a useful parameter of the effectiveness that microbial consortium has. In addition, it has been reported that soil microorganisms could help plants compensate for deficiencies of immobile nutrients, such as $\mathrm{P}$ and $\mathrm{K}$, by the increase of root biomass due to the production of phytohormones, which can mediate the extent of a greater root surface area for nutrients uptake (Bashan et al., 2014). It can be concluded that the activity of the inoculated MC plus HA can improve nutrient uptake by blueberries with the exception of $\mathrm{P}$.

In terms of physicochemical soil properties, the MC and HA treatments did not affect the soil considering most of the evaluated soil properties. Total $\mathrm{N} \mathrm{lev-}$ els and nitrate in the soil did not increase in 2 of the treatments evaluated ( $\mathrm{MC}$ and $\mathrm{MC}+\mathrm{HA}$ ), and even a decrease in nitrate content was observed in the MC and $\mathrm{MC}+\mathrm{HA}$ treatment. This may be explained by the assimilation of $\mathrm{N}$ by the microorganisms inoculated into the soil. However, we found an increase in nitrate uptake mediated by the HA treatment. In fact, it has been suggested that the addition of humic acid results in an increase of nitrate levels (Kolodziej et al., 2013). Besides, humic acid induces H+-ATPase activity that, in turn, can energize secondary ion transporters and promote nitrate uptake. Nitrate transport across the plasma membrane is facilitated by ion channels (Canellas et al., 2015). Nardi et al. (2000) reported an $89 \%$ increase compared to the unamended control as a result of the addition of humic acid. Furthermore, Jannin et al. (2012) used a q-PCR analysis for the expression of genes encoding nitrate transporter and reported an induction of these genes in roots of Brassica napus treated with humic acid.

Our results are in agreement with those found by other authors, who reported that the use of microbial consortium did not have beneficial effects on soil inoculated by microbial consortium in field conditions. For instance, Esitken et al. (2010) did not find significant difference in soil $\mathrm{pH}$, organic matter and $\mathrm{K}$ content after three years of experiment. Similarly, no differences were found on $\mathrm{N}$ and $\mathrm{K}$ contents in the soil (Chauhan and Bagyaraj 2015; Orhan et al., 2006). Information on the beneficial effects of humic acid has been well documented in terms of the physical properties of the soil under field conditions $(\mathrm{Xu}$ et al., 2015). However, humic substances showed no effect on the soil in most of the physical soil properties evaluated in our experiment. Humic acid products vary considerably in their chemical composition, undoubtedly reflecting differences in leonardite deposits from which they originated or in extraction techniques (Hartz and Bottoms 2010). Thus, implications for the physical soil properties are limited. This lack of beneficial effects on the soil when evaluating the 
application of humic acid agrees with the results of Hartz and Bottoms (2010). They concluded that humic acid had no effects on properties of the soil and plant productivity.

In this study, we found that the structure of bacterial communities (PCR-DGGE profiles) present in the rhizosphere of blueberry seedlings were significantly affected by $\mathrm{MC}+\mathrm{HA}$ and $\mathrm{HA}$ treatments but not in the rhizosphere of blueberry seedlings inoculated with microbial consortium (Figure 1). Microbial inoculants that are introduced into the soil must compete with indigenous microorganisms that are well adapted to the local environment. Many reports suggest that microbial inoculants do not have noticeable effects on the soil microbial community structure using low-resolution methods based on 16S rRNA gene profiles (Herschkovitz et al., 2005). Microorganisms interact with humic acids in the soil and rhizosphere environments in different ways (Puglisi et al., 2013). Humic acid is known for its capacity to deeply influence the structure and activity of soil bacterial communities (Dong et al., 2009; Puglisi et al., 2013). In this study, PCRDGGE and nMDS analysis revealed that the structure of rhizosphere bacterial communities was changed by all HA treatments, but not in fungal communities. The structural and chemical complexity of humic materials added seems to be a key factor for their utilization by heterotrophic microbial community (Puglisi et al., 2013). Humic acids are among the most complex and biological active compounds in the soil. Their indirect effects include induced changes in the structure and activity of soil microbial communities. The influence of humic acids on soil microbial communities still lacks a complete understanding (Puglisi et al., 2013), especially in terms of soil fungal communities. Our results also show that the bacterial diversity was not significantly affected by the treatments, whereas fungal diversity was significantly affected as revealed by the Shannon index. These results contrast with the differences observed using annMDS analysis (Figures 1 and 2). The differences may be due to the differences in the two approaches. The nMDS analysis approach does not only analyze the DGGE banding patterns (Bray-Curtis dissimilarity index), but also assigns a weight to the fluorescence of each band related to the abundance of specific bacterial or fungal with same gene sequence (Jorquera et al., 2014). In the case of fungal communities, we could hypothesize that the increased Shannon index produced by the application of treatments could be more closely related to the effect on the abundance than the diversity of fungal groups in the rhizosphere of blueberry seedlings. Finally, PCR-DGGE combined nMDS analysis revealed that $\mathrm{MC}+\mathrm{HA}$ and $\mathrm{HA}$ applications induced changes in the bacterial community structure, suggesting that $\mathrm{MC}+\mathrm{HA}$ and $\mathrm{HA}$ applications could modify the bacteriological characteristics of the rhizosphere of blueberry seedlings.

\section{Conclusions}

The combined application of microbial consortium and humic substances improves blueberry plant performance in volcanic soils, resulting in a synergistic effect when beneficial microorganisms and humic substances are introduced. Regarding chemical soil properties, the application of humic substances alone resulted in an increase in nitrate content. Based on these data, application of the combined treatments including microbial consortium and humic substances seems to be the most appropriate method to improve nutrient uptake, increase plant biomass and stimulate soil microflora. Application of the combined treatments produced vigorous seedlings and increased growth and nutrient content in Chilean Andisol. Therefore, the application of humic substances in combination with microbial consortium can be a 
biotechnological tool for plant growth promotion in sustainable agriculture systems.

\section{Acknowledgements}

This study was supported bythe Vice Presidency of Research and Development of the University of Concepción, Chile (Project VRID number 215.123.014$1.0 \mathrm{IN})$

\section{References}

Adesemoye, A.O., Torbert, H.A., Kloepper, J.W. 2009. Plant growth-promoting rhizobacteria allow reduced application rates of chemical fertilizers. Microb. Ecol. 58, 921-929.

Basak, B.B., Biswas, D.R. 2010. Co-inoculation of potassium solubilizing and nitrogen fixing bacteria on solubilization of waste mica and their effect on growth promotion and nutrient acquisition by a forage crop. Biol. Fertil. Soils. 46, 641-648.

Bashan, Y., de-Bashan, L.E., Prabhu, S.R., Hernandez, J.P. 2014. Advances in plant growth-promoting bacterial inoculant technology: formulations and practical perspectives (1998-2013). Plant Soil. 378, 1-33.

Blake, G.R., Hartge, K.H. 1986. Bulk density, in: Klute, A. (Ed.), Methods of soil analysis, 2nd edn. ASA and SSSA, Madison, pp. 363-375.

Canellas, L.P., Olivares, F.L., Aguiar, N.O., Jones, D.L., Nebbioso, A., Mazzei, P., Piccolo, A. 2015. Humic and fulvic acids as biostimulants in horticulture. Sci. Hort. 196, 15-27.

Canellas, L.P., Olivares, F.L. 2014. Physiological responses to humic substances as plant growth promoter. Chem. Biol. Technol. Agric. 1, 1-11.

Chauhan, H., Bagyaraj, D.J. 2015. Inoculation with selected microbial consortia not only enhances growth and yield of French bean but also reduces fertilizer application under field condition. Sci. Hort. 197, 441-446.

Couillerot, O., Ramirez-Trujillo, A., Walker, V. 2013. Comparison of prominent Azospirillum strains in Azospirillum-Pseudomonas-Glomus consortia for promotion of maize growth. Appl. Microbiol. Biotechnol. 97(10), 4639-4649.

Del Pozo, A., Del Canto, P. 1999. Áreasagroclimáticas y sistemasproductivos en la VII y VIII Regiones. Instituto de Investigaciones Agropecuarias, Centro Regional de Investigación Quilamapu, Chillán, Chile.

Dong, L., Córdova-Kreylos, A.L., Yang, J., Yuan, H., Scow, K.M. 2009. Humic acids buffer the effects of urea on soil ammonia oxidizers and potential nitrification. Soil Biol. Biochem. 41, 1612-1621.

Esitken, A., Yildiz, H.E., Ercisli, S., Donmez, M.F., Turan, M., Gunes, A. 2010. Effects of plant growth promoting bacteria (PGPB) on yield, growth and nutrient content of organically grown strawberry. Sci. Hort. 124, 62-66.

Girvan, M.S., Bullimore, J., Pretty, J.N., Osborn, A.M., Ball, A.S. 2003. Soil type is the primary determinant of the composition of the total and active bacterial communities in arable soil. Appl. Environ. Microbiol. 69, 1800-1809.

Hartz, T.K., Bottoms, T.G. 2010. Humic substances generally ineffective in improving vegetable crop nutrient uptake or productivity. HortScience. 45, 906-910.

Herschkovitz, Y., Lerner, A., Davidov, Y., Okon, Y., Jurkevitch, E. 2005. Azospirillum brasilense does not affect population structure of specific rhizobacterial communities of inoculated maize (Zea mays). Environ. Microbiol. 7, 1847-1852.

Jannin, L., Arkoun, M., Ourry, A. 2012. Microarray analysis of humic acid effects on Brassica napus 
growth: involvement of N, C and S metabolisms. Plant Soil. 359, 297-319.

Jha, C.K., Saraf, M. 2012. Evaluation of multispecies plant-growth promoting consortia for the growth promotion of Jatrophacurcas L. J. Plant Growth Regul. 31, 588-598.

Jorquera, M.A., Hernández, M.T., Martínez, O., Marschner, P., Mora, M.L. 2010. Detection of aluminium tolerance plasmids and microbial diversity in the rhizosphere of plants grown in acidic volcanic soil. Eur. J. Soil Biol. 46, 255-263.

Jorquera, M.A., Martínez, O.A., Marileo, L.G., Acuña, J.J., Saggar, S., Mora, M.L. 2014. Effect of nitrogen and phosphorus fertilization on the composition of rhizobacterial communities of two Chilean Andisol pastures. World J. Microb. Biot. 30, 99-107.

Klute, A. 1986. Water retention: laboratory methods. In Methods of soil analysis: part I. Physical and mineralogical methods, 2nd edn. American Society Agronomy/Soil Science Society of America, Madison, pp. 635-662.

Kolodzieg, B., Sugier, D., Bielinska, E. 2013. The effect of leonardite application and various plantation modalities on yielding and quality of roseroot (Rhodiolarosea L.) and soil enzymatic activity. J. Geochem. Explor. 129, 64-69.

Nardi, S., Pizzeghello, D., Gessa, C., Ferrarese, L., Trainotti, L., Casadoro, G. 2000. Alow molecular weight humic fraction on nitrate uptake and protein synthesis in maize seedlings. Soil Biol. Biochem. 32, 415-419.

Oficina de Estudios y PolíticasAgrarias (Chile) (2014) Superficie de frutalesporregión. (On line). www. odepa.cl/superficie-de-frutales-por-region-2/. (accessed 23 September 2014).

Olivares, F.L., Aguiar, N.O., Rosa, R.C.C., Canellas, L.P. 2015. Substrate biofortification in combination with foliar sprays of plant growth promoting bacteria and humic substances boosts production of organic tomatoes. Sci. Hortic. 183, 100-108.

Orhan, E., Esitken, A., Ercisli, S., Turan, M., Fikrettin, S. 2006. Effects of plant growth promoting rhizobacteria (PGPR) on yield, growth and nutrient contents in organically growing raspberry. Sci. Hort. 111, 38-43.

Pirlak, L., Köse, M. 2009. Effects of plant growth promoting rhizobacteria on yield and some fruit properties of strawberry. J. Plant Nutr. 32, 11731184.

Puglisi, E., Pascazio, S., Suciu, N., Cattani, I., Fait, G., Spaccini, R., Crecchio, C., Piccolo, A., Trevisan, M. 2013. Rhizosphere microbial diversity as influenced by humic substance amendments and chemical composition of rhizodeposits. J. Geochem. Explor. 129, 82-94.

Retamales, J.B., Palma, M.J., Morales, Y.A., Lobos, G.A., Moggia, C.E., Mena, C.A. 2014. Blueberry production in Chile: current status and future developments. Rev. Bras. Frutic. 36, 58-67.

Rose, M.T., Patti, A.F., Little, K.R., Brown, A.L.2014. A meta-analysis and review of plant-growth response to humic substances: practical implications for agriculture. Adv. Agron. 124, 37-89.

Sadzawka, A., Grez, R., Carrasco, M., Mora, M. 2007. Métodos de análisis de tejidos vegetales, CNA Comisión de Normalización y Acreditación. Sociedad Chilena de la Ciencia del Suelo, Santiago, Chile.

Sadzawka, A., Carrasco, M., Grez, R., Mora, M., Flores, H., Neaman, A. 2006. Métodos de análisis recomendados para los suelos de Chile. Instituto de Investigaciones Agropecuarias, Santiago, Chile

Sandoval, M.A., Stolpe, N., Zagal, E., Mardones, M. 2007. The effect of crop-pasture rotation on the C, $\mathrm{N}$ and $\mathrm{S}$ contents of soil aggregates and structural stability in a volcanic soil of south-central Chile. Acta Agric. Scand. B. 57, 255-262. 
Singh, S.R., Zargar, M.Y., Singh, U., Ishaq, M.2010. Influence of bio-inoculants and inorganic fertilizers on yield, nutrient balance, microbial dynamics and quality of strawberry (Fragariax ananassa) under rainfed conditions of Kashmir valley. Indian J. Agric. Sci. 80, 275-281.

Schoebitz, M., Vidal, G. 2016. Microbial consortium and pig slurry to improve chemical properties of degraded soil and nutrient plant uptake. J. Soil Sci. Plant Nutr. 16 (1), 226-236

Soil-Survey-Staff. 2006. Soil Taxonomy: A Basic System of Soil Classification for Making and Interpreting Soil Surveys. US Government Printing Office, Washington.
Thilagar, G., Bagyaraj, D.J., Rao, M.S. 2016. Selected microbial consortia developed for chilly reduces application of chemical fertilizers by $50 \%$ under field conditions. Sci. Hort. 198, 27-35.

Viscardi, S., Ventorino, S., Duran, P., Maggio, A., De Pascale, S., Mora, M.L., Pepe, O. 2016. Assessment of plant growth promoting activities and abioticstress tolerance of Azotobacter chroococcum strains for apotential use in sustainable agriculture. J. Soil Sci. Plant Nutr. 16 (3), 848-863

Xu, S., Zhang, L., McLaughlin, N.B., Mi, J., Chen, Q., Liu, J. 2015. Effect of synthetic and natural water absorbing soil amendment soil physical properties under potato production in a semi-arid region. Soil Til. Res. 148, 31-39. 